\title{
Perceived factors that influence energy consumption
}

\author{
A. H. Araghi \& E. Sakhaee \\ Department of Civil Engineering, University of Sydney, Australia
}

\begin{abstract}
Currently, energy consumption is one of the significant problems in many developed and developing countries around the world. This research investigates the perceived factors that contribute to energy consumption as viewed by employees of construction companies in four countries - USA, China, Taiwan and Iran. The primary interest is to see if there are cultural, geographical and other situational (such as price of oil) factors that affect these perceptions. Results have been obtained via surveys of each of the countries to demonstrate these differences and solutions that have emerged from the masses from each country have been identified.

Keywords: energy wastage, fossil fuel emissions, solving energy consumption, non-renewable energy sources, renewable energy sources.
\end{abstract}

\section{Introduction}

Today, with the economic development, the industrial area continues to consume large amount of energy [1]. EIA (2013) reports that world energy consumption will raise $56 \%$ by 2040 according to the EIA projects [1]. Accordingly, the high demand of fossil fuel emissions of $\mathrm{CO}_{2}$ leads to air pollution and climate change [2]. Figure 1(a) and Figure 1(b) show the $\mathrm{CO}_{2}$ emissions in different areas around the world [3] over time.

This research is going to investigate the perceived important factors that affect energy consumption in five countries around the world, namely USA, China, Taiwan, and Iran and also focus on diverse measure to alleviate this issue. 


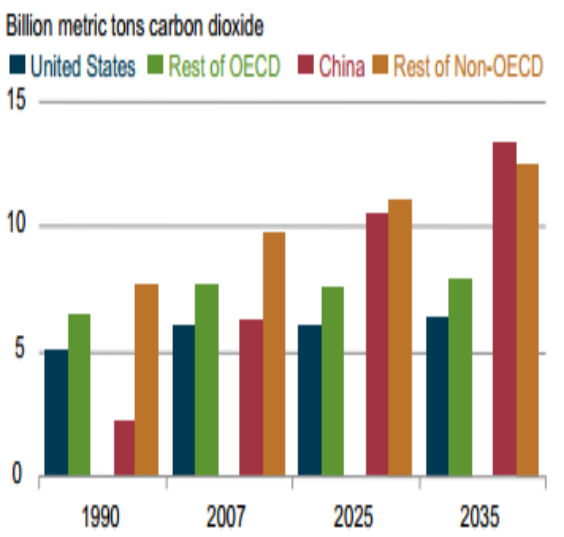

(a)
Percent of world total

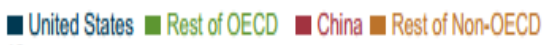

40

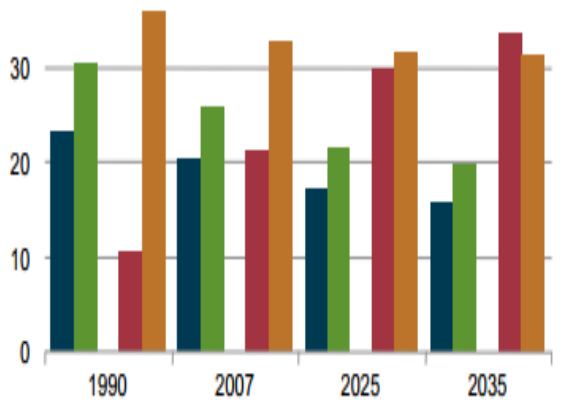

(b)

Figure 1: (a) World $\mathrm{CO}_{2}$ emissions by region 1990, 2007, 2025, and 2035; (b) regional shares of world $\mathrm{CO}_{2}$ emissions 1990, 2007, 2025, and 2035 .

The perceived factors in energy consumption can be divided into several aspects. Firstly, some countries have relatively large amounts of non-renewable energy resources compared to other nations (such as many of the Middle Eastern countries), and the price of oil, gas, and petrol is relatively cheap in these countries [4]. Secondly, there is a lack of adequate public education on problems caused by non-renewable energy consumption, and lack of knowledge about benefits that can be gained from using renewable energy [5]. Thirdly, poor housing development plans such as using low quality material to make different types of structures, especially houses [6]. Finally, low quality of transportation system which is included do not have enough buses and trains compared with population or prices of transportation is more expensive compared with facilities provided for passengers [7].

The ways of eliminating the problem could be divided into few aspects. First of all, accompanying with the development of economic and innovative technology, it is possible to improve the existing technology to solve the problem. It means that each area has an abundance of one or two renewable sources such as solar power, wind power, water power, ethanol biofuels, geothermal, hydrogen, and photovoltaic or energy recovery from waste [8]. Therefore, with developing appropriate technologies in each area can utilise these kinds of sources for producing energy instead of using from un-renewable energies.

Secondly, increasing the energy efficiency with reconstructing interior decoration of houses, apartments and office buildings, which means adapting the energy-efficient doors, windows and skylights. Such activities could contribute to lower a house's heating, cooling and lighting demands; thus, it could help to reduce the volume of energy consumption. Furthermore, using energy-saving products, such as compact fluorescent lamps, less electricity consumption refrigerator, washing machines, air-conditioning, etc. [9]. 
Thirdly, encouraging the public to take public transport system by improving quality of public transportation system such as buses and trains [10] can reduce traffic and air pollution while reducing the use of non-renewable energy (such as petrol and gas). Furthermore, private sectors should call for joint effort with government to educate the awareness of reducing usage of fossil fuels by informing the public about the negative effects of using fossil fuels such as carbon dioxide emissions.

Additionally, increasing prices of oil, gas, and, petrol could encourage people to save energy in order to keep the costs down [11]. Moreover, implementing technologies that utilise renewable energy such as putting solar panel on houses and apartments to provide heating energy.

Last but not least, form the perceptive of environmental sustainability, building green building is another option. Green construction is a structure using energy, water and other resources efficiently and concerning comfort, durability, utility and economy [12]. Moreover, the materials of building this kind of houses usually rely on the local environment [9]. Therefore, it helps to reduce waste, pollution and environmental degradation.

Energy is the centre of most critical economic, environmental and developmental problem in modern world [13]. Over the last century, the population of the world is increasing rapidly, and International Energy Outlook 2013 projects predict that energy consumption will increase 56\% until 2040 [1]. Additionally, Abulfotuh [14] presents that the portion of global major energy demand used in electricity production are not low and the growth rate for this segment is predicted to surpass $50 \%$ in 2060 .

This research investigates the perceived factors that contribute to energy consumption as viewed by employees of construction companies in four countries - USA, China, Taiwan and Iran. The primary interest is to see if there are cultural, geographical and other situational factors (such as price of oil) that affect these perceptions. Results have been obtained via surveys of each of the countries to demonstrate these differences and solutions that have emerged from the masses from each country have been identified.

\section{Methodology}

The instruments for this research will be a quantitative method investigating perceived common causes of energy wastage in various countries and also identifying possible solution for bridging the gap in each country under study. The questionnaire is 30 multiple choice questions made by REDCap software would be used as principle instrumentation the online survey and data collection. We will send questionnaires to participants around the world and collect relative documentations from their answers.

The result of this research is based on online survey results. This survey includes 13 multiple choice questions. From questions 1 to 13 we use a Likert scale of five-levels for each question indicating the perceived importance of the factor in energy saving: 


$\begin{array}{lllll}5 & 4 & 3 & 2 & 1\end{array}$

In this survey choosing 5 means that mentioned factor is very important and choosing 1 means less important. Questions 1-7 exhibit a problem, and questions $8-13$ reflect most effective solutions. The last question obtains the demographics of the survey participant, including gender, position of person in company, age, education level, and country that he/she is currently working in. The survey is anonymous and no personal or identifiable data is collected.

During the analysis phase, after all survey data is collected from our participants, we will calculate the average of points for each question for each country. Consequently, we will find which parameters have are seen to have the most significant role for wasting energy in USA, China, Taiwan, and, Iran, and which solutions are perceived to be most effective in solving the energy consumption problem - or at least decrease energy wastage in the corresponding countries studied. The below formulae is used, where $n$ is the number that each participant selects for each question, reflecting perceived importance.

$$
\text { Average }=\frac{\sum n}{\text { Number of participants in each country }}
$$

The target participants are employees and owners of construction companies in each of the target countries. Surveys are sent to the companies' employees anonymously.

\section{Results and analysis}

Table 1: USA (number of participants 100).

\begin{tabular}{|c|c|c|}
\hline Rank & Perceived factors for energy consumption & Average (max 5) \\
\hline $\mathbf{1}$ & $\begin{array}{c}\text { Lack of knowledge about benefits that can be } \\
\text { gained from using renewable energy }\end{array}$ & 4.23 \\
\hline $\mathbf{2}$ & $\begin{array}{c}\text { Lack of adequate public education on problems } \\
\text { due to energy wastage }\end{array}$ & 4.21 \\
\hline $\mathbf{3}$ & Cheap prices of oil, gas, and petrol & 4.05 \\
\hline $\mathbf{4}$ & Having huge resources of non-renewable energy & 4.02 \\
\hline $\mathbf{5}$ & Low quality of transportation system & 3.35 \\
\hline $\mathbf{6}$ & Poor housing development plans & 3.21 \\
\hline
\end{tabular}


Table 2: USA (number of participants 100).

\begin{tabular}{|c|c|c|}
\hline Rank & Perceived factors for solving consumption & Average (max 5) \\
\hline $\mathbf{1}$ & $\begin{array}{c}\text { Increasing the quality of public education on } \\
\text { better energy usage }\end{array}$ & 4.58 \\
\hline $\mathbf{2}$ & Increasing prices Energy of oil, gas, and petrol & 4.47 \\
\hline $\mathbf{3}$ & Increasing use of renewable energy & 4.45 \\
\hline $\mathbf{4}$ & $\begin{array}{c}\text { Improving the quality of new houses (for } \\
\text { example use double glazed windows) }\end{array}$ & 4.82 \\
\hline $\mathbf{5}$ & Improving the quality of transportation system & 3.75 \\
\hline
\end{tabular}

Table 3: China (number of participants 100).

\begin{tabular}{|c|c|c|}
\hline Rank & Perceived factors for energy consumption & Average (max 5) \\
\hline $\mathbf{1}$ & Poor housing development plans & 4.12 \\
\hline $\mathbf{2}$ & Cheap prices of oil, gas, and petrol & 4.09 \\
\hline $\mathbf{3}$ & $\begin{array}{c}\text { Lack of adequate public education on problems } \\
\text { due to energy wastage }\end{array}$ & 4.05 \\
\hline $\mathbf{4}$ & $\begin{array}{c}\text { Lack of knowledge about benefits that can be } \\
\text { gained from using renewable energy }\end{array}$ & 2.02 \\
\hline $\mathbf{5}$ & Low quality of transportation system & 2.72 \\
\hline $\mathbf{6}$ & $\begin{array}{c}\text { Having huge resources of non-renewable energy } \\
\text { in your country }\end{array}$ & \\
\hline
\end{tabular}

Table 4: China (number of participants 100).

\begin{tabular}{|c|c|c|}
\hline Rank & Perceived factors for solving consumption & Average (max 5) \\
\hline $\mathbf{1}$ & $\begin{array}{c}\text { Improving the quality of new houses (for } \\
\text { example use double glazed windows) }\end{array}$ & 4.38 \\
\hline $\mathbf{2}$ & Increasing use of renewable energy & 4.28 \\
\hline $\mathbf{3}$ & Increasing prices of oil, gas, and petrol & 4.19 \\
\hline $\mathbf{4}$ & $\begin{array}{c}\text { Increasing the quality of public education on } \\
\text { better energy usage }\end{array}$ & 4.09 \\
\hline $\mathbf{5}$ & Improving the quality of transportation system & 2.91 \\
\hline
\end{tabular}


Table 5: Taiwan (number of participants 100).

\begin{tabular}{|c|c|c|}
\hline Rank & Perceived factors for energy consumption & Average (max 5) \\
\hline $\mathbf{1}$ & Poor housing development plans & 4.26 \\
\hline $\mathbf{2}$ & Cheap prices of oil, gas, and petrol & 4.07 \\
\hline $\mathbf{3}$ & $\begin{array}{c}\text { Lack of adequate public education on problems } \\
\text { due to energy wastage }\end{array}$ & 3.02 \\
\hline $\mathbf{4}$ & $\begin{array}{c}\text { Lack of knowledge about benefits that can be } \\
\text { gained from using renewable energy }\end{array}$ & 1.98 \\
\hline $\mathbf{5}$ & Low quality of transportation system & 1.25 \\
\hline $\mathbf{6}$ & Having huge resources of non-renewable energy & \\
\hline
\end{tabular}

Table 6: Taiwan (number of participants 100).

\begin{tabular}{|c|c|c|}
\hline Rank & Perceived factors for solving consumption & Average (max 5) \\
\hline $\mathbf{1}$ & Increasing use of renewable energy & 4.66 \\
\hline $\mathbf{2}$ & $\begin{array}{c}\text { Improving the quality of new houses (for } \\
\text { example use double glazed windows) }\end{array}$ & 4.32 \\
\hline $\mathbf{3}$ & Increasing prices of oil, gas, and petrol & 4.25 \\
\hline $\mathbf{4}$ & $\begin{array}{c}\text { Increasing the quality of public education on } \\
\text { better energy usage }\end{array}$ & 4.23 \\
\hline $\mathbf{5}$ & Improving the quality of transportation system & 3.26 \\
\hline
\end{tabular}

Table 7: Iran (Number of Participants 100)

\begin{tabular}{|c|c|c|}
\hline Rank & Perceived factors for energy consumption & Average (max 5) \\
\hline $\mathbf{1}$ & Cheap prices of oil, gas, and petrol & 4.91 \\
\hline $\mathbf{2}$ & $\begin{array}{c}\text { Having huge resources of non-renewable energy } \\
\text { in your country }\end{array}$ & 4.69 \\
\hline $\mathbf{3}$ & $\begin{array}{c}\text { Lack of adequate public education on problems } \\
\text { due to energy wastage }\end{array}$ & 4.34 \\
\hline $\mathbf{4}$ & $\begin{array}{c}\text { Lack of knowledge about benefits that can be } \\
\text { gained from using renewable energy }\end{array}$ & 3.56 \\
\hline $\mathbf{5}$ & Poor housing development plans & 3.44 \\
\hline $\mathbf{6}$ & Low quality of transportation system & \\
\hline
\end{tabular}


Table 8: Iran (number of participants 100).

\begin{tabular}{|c|c|c|}
\hline Rank & Perceived factors for solving consumption & Average (max 5) \\
\hline $\mathbf{1}$ & Increasing prices of oil, gas, and petrol & 4.83 \\
\hline $\mathbf{2}$ & Increasing use of renewable energy & 4.68 \\
\hline $\mathbf{3}$ & $\begin{array}{c}\text { Increasing the quality of public education on } \\
\text { better energy usage }\end{array}$ & 4.25 \\
\hline $\mathbf{4}$ & $\begin{array}{c}\text { Improving the quality of new houses (for } \\
\text { example use double glazed windows) }\end{array}$ & 4.23 \\
\hline $\mathbf{5}$ & Improving the quality of transportation system & 3.91 \\
\hline
\end{tabular}

\section{Discussion}

This section compares the results from target countries and explores why some factors may be seen to be more important while other factors less important in each country.

\subsection{Discussion about perceived factors for energy consumption}

The first factor that this research is going to discuss about is cheap prices of oil, gas, and petrol. According to the results shown in (Table 7) this factor is seen as the most important factor in energy consumption in Iran. However, this factor has second rank in China (Table 3), and Taiwan (Table 5), also third rank in USA (Table 1). Because Iran has the second largest gas resource in the world (first being Russia) and also large resources of oil so the price of fuels are much cheaper compare with other countries. For instance, currently the price of petrol is around \$0.30USD per litre in Iran. Therefore, unfortunately very high amounts of fossil fuels are being used up in Iran every day. However, the price of fossil fuels in USA, China, and Taiwan is relatively higher than Iran and the importance of this factor is not the same as Iran, but still compare with average income people can gain in these countries, the price of fossil fuels are seen to be not very high.

Second factor that this research is going to explain is lack of adequate public education on problems due to energy wastage. According to table results this factor is the second significant factor in USA (Table 1), and also third important factor in China (Table 3), Taiwan (Table 5), and Iran (Table 7). However, currently most of countries are trying to increase public education about negative effects that wasting energy has for human, animals, and environment by different ways such as advertisement on media, public billboards and at schools and educational institutions. Conversely still large percentage of the population in most societies do not have adequate knowledge on energy consumption and sustainability.

Third factor is about having huge resources of non-renewable energy in some countries. This factor has different ranking between mentioned countries. However, this factor is second important factor in Iran (Table 7), and fourth significant factor in USA (Table 1). However in China, and Taiwan this is the least important factor among all perceived factors (Tables 3 and 5). Iran and USA has 
huge resources of non-renewable energy in their country and sometimes cost of using non-renewable energy is cheaper than using renewable energy in these country, because they do not import fuel from other countries. However, USA has the highest amount of resources of oil in the world. On the other hand, Taiwan and China does not have large resources of non-renewable energy compare with population are living there.

Fourth factor is the lack of knowledge about benefits that can be gained from using renewable energy in energy consumption. According to analysis data part, this factor is the most important factor in USA (Table 1), also is fourth significant factor in China (Table 3), Taiwan (Table 5), and Iran (Table 7). However, USA is one of the pioneer countries in using renewable energy in the world, but most of renewable energy projects are large projects are supported by the government, and using renewable energy at small scale in houses is not common compare to some other countries.

Fifth factor is poor housing development plans. This factor is most important perceived factor in energy consumption in China (Table 3) and Taiwan (Table 5). Also it ranks $5^{\text {th }}$ in Iran (Table 7) and $6^{\text {th }}$ in USA (Table 1). Although in some part of China and Taiwan, in particular the main tourist and commercial areas, modern buildings dominantly exist, from the survey it seems that large number of population in these countries are living in old houses with traditional structures, this factor seems more in China, because China is one the largest countries in the world the largest population. Although Chinese citizens are living in big cities like Beijing and Shanghai usually live in modern houses with standard quality, but large percentage of the population are living in villages and small cities where the quality of their houses are below standard [15]. This could consequently cause large amount of energy used for heating houses is dissipated through walls, windows, roofs, and doors.

Another important factor is low quality of transportation system. This factor is $6^{\text {th }}$ most perceived significant factor in Iran (Table 7), and also $6^{\text {th }}$ in China (Table 3), Taiwan (Table 5), and USA (Table 1) in energy consumption. Currently, all of the mentioned countries have good facilities in transportation system and large percentage of the population in all of mentioned countries utilizing the diverse types of public transport available. The cost of public transport could also contribute to its increased or decreased use by the public. If the public see it as a cost-effective way to travel, it would incentivize individuals to take public transport in oppose to driving to work for example.

\subsection{Discussion about perceived factors for solving energy consumption}

In this section we discuss the most efficient perceived solution to solve energy consumption in the studied countries.

The first perceived important factor is the increasing prices of oil, gas, and petrol. Participants on the survey chose this factor as best solution for solving energy consumption problem in Iran (Table 8). Also this factor is second important factor in USA (Table 2), and third significant factor in China (Table 4) and Taiwan (Table 6). Currently, the price of fuels in most of Middle East countries, such as Iran is much cheaper compared with countries are located in other areas in the 
world. Moreover usually the price of fuels is cheaper in America compare with Asian countries like China and Taiwan particularly when the price of fuels compare with the average income of people. Because average salary in USA is more than China and Taiwan [16]. Therefore, increasing price of oil, gas, and petrol firstly, can be more effective in Iran, and secondly more effective in USA compare with China and Taiwan. However, generally increase price of fuels can be effective in reducing energy consumption all countries around the world.

The second perceived factor is the importance of increasing the quality of public education in relation to better usage of energy. Research found that this factor is the best solution to solve the energy consumption issue in the USA (Table 2). In contrast, this factor was deemed of third importance as a solution in Iran (Table 8), and interestingly it ranked of $4^{\text {th }}$ importance in China (Table 4) and Taiwan (Table 6). However in last two decades, the US government implemented a range of measures to reduce energy consumption in the country, but most of the projects were large in scale as they were related to government projects. Therefore, currently the most efficient action would be to increase the quality of public education in relation to better energy usage. However, increasing the quality of public education on better energy usage should be support by all government, because having knowledge about how to better use energy will be more important in the future by reducing fossil fuels resource consumption around the world.

Improving the quality of transportation system is another important factor to solve energy consumption problem. This factor is less significant factor in USA (Table 2), China (Table 4), Taiwan (Table 6), and Iran (Table 8). Because currently all of mentioned countries have acceptable transportation system especially in huge cities. However, usually Asian countries have better transportation system compare with other countries, because using public transport in Asian countries is cheaper and faster.

Improving the quality of new houses such as using double glazed windows can be another important solution to solve energy consumption problem. This research found this factor to be the most significant perceived factor in energy consumption in China (Table 4). However, most of large cities in China have houses with standard quality but in rural areas many houses are below than standard, and energy wastage rate is high in these kinds of houses [15], so government and other organizations should find one useful solution to solve this problem as soon as possible. On the other hand, improving the quality of new houses is second important solution in Taiwan (Table 6), also it is $4^{\text {th }}$ significant factor in USA (Table 2) and Iran (Table 8). However, improving the quality of new houses can be effective solution in all of mention countries, but this solution will be more useful in China, because population are living in rural areas in China are larger compare with USA, Taiwan, and Iran.

Increasing the use of renewable energy is another solution to solve energy consumption problem in the studied countries. Participants involved this research chose that increasing use of renewable energy can be most effective way for solving energy consumption in Taiwan (Table 6). Because, today Taiwan is suffering from lack of huge fossil fuels resources, and they import huge amount of fossil fuels from overseas. Furthermore, increasing use of renewable energy is 
second significant factor in China (Table 4) and Iran (Table 8), also it is third in USA (Table 2). However, usually renewable energy projects need large amount of resources and investment to be completed, since fossil fuels resources are nonrenewable so investment on project for producing renewable energy can be a permanent solution to solve energy consumption issue forever.

\section{Conclusion}

According to the results in the previous section, although all of mentioned factors are perceived to be effective in minimising energy wastage, each country possesses one major factor that dominates and has the most significant effect on total energy consumption of the country. In order to effectively implement strategies to minimise the energy consumption problem, it would be worthwhile to utilize the "wisdom of the masses" - as the factors that are perceived to be the most important and significant are more likely to win the hearts of the people in the target society when implemented. What is important in intrinsically motivating a society for implementing change is to understand the current perceptions of the people and leverage off such an understanding. For example in the USA, "lack of knowledge about benefits that can be gained from using renewable energy" and "lack of adequate public education on problems due to energy wastage" indicates that the target audience would appreciate if matters related to energy consumption are treated by implementing a strategy to better educate the public on the benefits that can be gained using renewable energy as well as the problems caused by careless energy consumption. In China however, the majority of the target audience would appreciate if the same problem is dealt with by improving the housing development plans and even raising the prices of oil, gas and petrol, perhaps by imposing higher taxes on these non-renewable resources. Effectively change can be implemented by considering the knowledge and wisdom of the public.

\section{References}

[1] EIA. (2013). International energy outlook 2013. Washington: EIA - US Energy Information Administration.

[2] Hansen, J., Sato, M., Ruedy, R., Lo, K., Lea, D. W., \& Medina-Elizade, M. (2006). Global temperature change. PNAS, Vol. 103 No. 39 pp. $14288-14293$.

[3] EIA. (2011). Emissions of greenhouse gases in the United states 2009. Washington: US department of Energy.

[4] Williamson, R. (2013). Bond Buyer. New YORK: SourceMedia.

[5] Al-Nimr, M. A. (2011). Renewable Energy - The Facts. Elsevier-Energy, Vol. 36, Issue 2, pp. 1376-1377.

[6] Boardman, B., Darby, S., Killip, G., Hinnells, M., Jardine, C. N., Palmer, J. \& Sinden, G. (2005). Building fabric and housing stock. Oxford: Environmental Change Institue, University of Oxford. 
[7] Hensher, D. A. (2005). Competition and ownership in land passenger transport. 8th International Conference (thredbo8). Rio de Janeiro: Elsevier Science Ltd.

[8] Singh, A., Pant, D., \& Olsen, S. (2013). Life Cycle Assessment of Renewable Energy Sources. Springer.

[9] Davey, L., \& Sherry, T. (2007, June). Energy efficent re-construction in New Orleans. Retrieved from Green Tulane: http://green.tulane.edu/PDFs/NOLA_Energy_Efficiency_Jun07.pdf

[10] Laffel, N. (2006, May 8). Promoting Public Transportation for Sustainable. Retrieved from Princeton: www.princeton.edu/ mauzeral/wws402d_s06/Laffel.pdf

[11] Becken, S., \& Lennox , J. (2012). Implications of a long term increase in oil prices for tourism. Tourism Management, Vol. 33, pp. 133-142.

[12] Kim, J.-J., \& Rigdon, B. (1998). Sustainable Architecture Module: Qualities, Use and Examples of Sustainable Building Materials. Michigan: National Pollution Prevention Center for Higher Education.

[13] AGECC. (2010). Energy for a sustainable future. New york: The secretarygeneral's advisory group on energy and climate change.

[14] Abulfotuh, F. (2007). Energy efficiency and renewable technologies: the way to sustainable energy future. Elsevier-Science Direct, pp. 275-282.

[15] How will a slowing China cope with rapidly aging buildings? (2013, June 28). Retrieved from China Economic Review: http://www.chinaeconomicreview.com/Unstable-Foundations-Part-2

[16] Said, S. (2013, February 6). The Top 10 Highest Average Salary Per Country. Retrieved from The Richest: www.therichest.com/business/thetop-10-highest-average-salary-per-country/10/ 